\title{
Re-emergence of Vibrio tubiashii in bivalve shellfish aquaculture: severity, environmental drivers, geographic extent and management
}

\author{
Ralph A. Elston ${ }^{1, *}$, Hiroaki Hasegawa ${ }^{2}$, Karen L. Humphrey ${ }^{1}$, Ildiko K. Polyak ${ }^{1}$, \\ Claudia C. Häse ${ }^{2}$ \\ ${ }^{1}$ AquaTechnics, 455 West Bell Street, Sequim, Washington 98382, USA \\ ${ }^{2}$ Department of Biomedical Sciences, College of Veterinary Medicine, Oregon State University, Corvallis, \\ Oregon 97331, USA
}

\begin{abstract}
During 2006 and 2007, we documented the re-emergence of severe episodes of vibriosis caused by Vibrio tubiashii in shellfish hatcheries on the west coast of North America. Lost larval and juvenile production included 3 previously undescribed hosts, Pacific (Crassostrea gigas) and Kumamoto (C. sikamea) oysters and geoduck clams Panope abrupta, with a 2007 decline in larval oyster production of $\sim 59 \%$ in one hatchery. Losses of larval and juvenile bivalves were linked to $V$. tubiashii blooms in the coastal environment, which were associated with the apparent mixing of unusually warm surface seawater and intermittently upwelled cooler, nutrient- and Vibrio spp.enriched seawater. The ocean temperature elevation anomaly in 2007 was not clearly linked to an El Niño event, as was a similar episode in 1998. Concentrations of the dominant shellfish-pathogenic vibrios were as high as $1.6 \times 10^{5} \mathrm{cfu} \mathrm{ml}^{-1}$ in the cold, upwelled water. The bacteria possessed the genes coding for a protease and hemolysin described for $V$. tubiashii, and pathogenic isolates secreted these peptides. Lesions resulting from a classic invasive disease and a toxigenic noninvasive disease occurred in oyster and geoduck clam larvae. Management and prevention require reduction of incoming concentrations of the bacteria, reduction of contamination in water and air supplies and in stock chemical solutions, removal of bacterial toxins, and interruption of the cycle of bacterial amplification in the hatchery and in microalgal food supplies.
\end{abstract}

KEY WORDS: Vibriosis · Vibrio tubiashii · Shellfish hatchery · Health management · Ocean warming

\section{INTRODUCTION}

Since 1998, we have annually investigated ocean waters, shellfish hatcheries, nurseries, and growing areas for the presence of shellfish-pathogenic vibrios and outbreaks of vibriosis in shellfish production hatcheries on the west and east coasts of the United States, Canada, Mexico, and from mid- to eastern Pacific Islands. In a previous paper, we characterized a number of pathogenic and nonpathogenic bacterial strains from moribund Pacific oyster Crassostrea gigas larvae from shellfish hatcheries on the North American Pacific Coast (Estes et al. 2004). Some of these highly pathogenic isolates were later confirmed to be Vibrio tubiashii, partly because they contained genes for a protease and a hemolysin (Hasegawa et al. 2008) coding for the exact peptide sequences previously described for $V$. tubiashii (Kothary et al. 2001, Delston et al. 2003).

Vibrio tubiashii was first recognized $>4$ decades ago as a significant pathogen of several species of bivalve larvae (Tubiash et al. 1965, 1970). The disease was initially termed bacillary necrosis, and the causative bacterium later designated as $V$. tubiashii by Hada et al. (1984). Subsequent papers and reviews described the pathogenesis of vibriosis and documented the importance of vibriosis in shellfish hatchery and nursery production (Brown 1973, 1981, Brown \& Losee 1978, Elston 
\& Leibovitz 1980, Elston et al. 1981, Elston 1984, 1999). Kothary et al. (2001) and Delston et al. (2003) showed that $V$. tubiashii produced both a protease and a cytolysin; Hasegawa et al. (2008) identified the gene coding for these proteins.

In this paper, we describe for the first time the detection of Vibrio tubiashii from the North American Pacific Coast and from previously unreported susceptible species of shellfish larvae and juveniles. We demonstrate strong evidence for an emerging resurgence of the prevalence and severity of $V$. tubiashii infection of earlylife-stage shellfish in 2006 and particularly in 2007. This resurgence appears to be partly related to unusually warm surface seawater temperature (SST) in 2007 along portions of the US Pacific Coast, and was responsible for an estimated loss of at least $59 \%$ of hatchery production at a key shellfish hatchery in that year. In addition, losses from other shellfish hatchery and nursery rearing facilities were accompanied by reports of failures of natural shellfish larval populations. To help explain the re-emergence of this disease and encourage urgently needed investigations, we present hypotheses regarding marine environmental conditions that appear to support high concentrations of $V$. tubiashii and other shellfishpathogenic vibrios. We provide detailed information on the management of the disease in shellfish hatcheries, based on analysis of bacteriological samples from specific hatcheries and locations in the marine environment.

\section{MATERIALS AND METHODS}

Collection of samples. Between 1998 and 2007, samples of algal cultures, air and seawater from hatchery systems, natural seawater, bivalve larvae, and juveniles were collected from locations on the Atlantic and Pacific coasts of North America and from Hawaii and the Marshall Islands (Table 1). Samples of larval and juvenile bivalves were taken from intensive commercial production facilities. Samples from remote locations were shipped to the laboratory in chilled state, and isolations made within $48 \mathrm{~h}$ of sampling. Stock algal cultures were screened from several hatcheries at 3 to 4 mo intervals.

Isolation of bacteria and growth conditions. Bacteria were isolated primarily on Difco Marine Broth (2216) with $1.5 \%$ agar added (hereafter 'marine agar'), and less frequently on Difco TCBS Agar. Liquid samples (seawater and microalgal culture) were plated in 10-fold dilutions. Larval and juvenile shellfish samples were first concentrated, weighed, and ground with a Kontes pestle and microtube. Larvae and very small seed were ground whole. We added $1 \mathrm{ml}$ of sterile sea water (SSW) to the ground tissue, and the microtube was vortexed thoroughly. Particulates, including shell, were allowed to settle out of the suspension and the supernatant then quantitatively plated using the same method as for liquid samples. Plates were incubated at $25^{\circ} \mathrm{C}$ for 24 to $48 \mathrm{~h}$ prior to counting and examination of colonies with a stereomicroscope. In some cases, plate counts were additionally assessed at $6 \mathrm{~d}$ after plate inoculation. Marine agar plate counts were analyzed from pressurized air lines or room air by exposing the plate to the air source between $30 \mathrm{~s}$ and $2 \mathrm{~min}$ or by leaving a plate open in test locations for up to $30 \mathrm{~min}$. Bacteria were stored in Difco Marine Broth (2216) with $15 \%$ glycerol at -55 to $-65^{\circ} \mathrm{C}$.

Characterization of bacteria. Selected isolates representative of various degrees of pathogenicity were archived between 1998 and 2007 and characterized for phenotypic and genetic markers (Tables $1 \& 2$ ). Isolates were characterized chemically and physiologically

Table 1. Sources of selected representative Vibrio spp. isolates from the Pacific Coast and Hawaii. NELHA: Natural Energy Laboratory of Hawaii Authority

\begin{tabular}{|c|c|c|c|c|}
\hline Isolate number & $\begin{array}{l}\text { Isolate number } \\
\text { assigned in Estes (2002) } \\
\text { or Estes et al. (2004) }\end{array}$ & Location & Source & Date isolated \\
\hline $\mathrm{X} 00-12-1$ & RE98 & Netarts, Oregon hatchery & Pacific oyster larvae & 1 Jun 2000 \\
\hline $00-90-9$ & RE90 & NELHA, Hawaii & Surface seawater lines & 22 Jun 2000 \\
\hline ATCC19109 & & American Type Culture Collection & & \\
\hline 99-70-6B2 & RE22 & Netarts, Oregon hatchery & Pacific oyster larvae & 17 Apr 1999 \\
\hline $00-90-6$ & RE87 & NELHA, Hawaii nursery & Pacific oyster seed & 22 Jun 2000 \\
\hline $00-90-7$ & RE88 & NELHA, Hawaii nursery & Pacific oyster seed & 22 Jun 2000 \\
\hline $00-90-5 a$ & RE86 & NELHA, Hawaii nursery & Pacific oyster seed & 22 Jun 2000 \\
\hline $07-52-1$ & & N. Hood Canal, Washington, hatchery & Geoduck clam larvae & 23 Mar 2007 \\
\hline $99-79-Y$ & RE15 & N. Hood Canal, Washington, hatchery & Pacific oyster larvae & 1 Jun 1999 \\
\hline $00-90-4$ & RE85 & NELHA, Hawaii nursery & Pacific oyster seed & 22 Jun 2000 \\
\hline $07-162-2$ & & Netarts Bay, Oregon & Flood-tide seawater & 10 Sep 2007 \\
\hline $00-90-5 b$ & RE86 & NELHA, Hawaii nursery & Pacific oyster seed & 22 Jun 2000 \\
\hline 06-106-1 & & N. Hood Canal, Washington, hatchery & Hatchery algae culture & 18 Sep 2006 \\
\hline 06-107-1 & & Yaquina Bay, Oregon hatchery & Pacific oyster juveniles & 19 Sep 2006 \\
\hline
\end{tabular}


Table 2. Characteristics of isolates. Vibrio spp. phenotype determined by described biochemical and physiological characteristics or confirmation by polyclonal antibody reactivity. Species key: P, Pacific oyster larvae; K, Kumamoto oyster larvae; G, geoduck clam larvae

\begin{tabular}{|c|c|c|c|c|c|c|}
\hline Isolate number & $\begin{array}{l}\text { Vibrio spp. } \\
\text { phenotype }\end{array}$ & $\begin{array}{l}\text { Protease } \\
\text { gene }\end{array}$ & $\begin{array}{l}\text { Hemolysin } \\
\text { gene }\end{array}$ & $\begin{array}{c}\text { Protease } \\
\text { activity }\end{array}$ & $\begin{array}{l}\text { Hemolytic } \\
\text { activity }\end{array}$ & $\begin{array}{l}\text { Association } \\
\text { with vibriosis }\end{array}$ \\
\hline X00-12-1 & + & + & + & +++ & ++ & $\mathrm{P}^{\mathrm{a}, \mathrm{b}, \mathrm{e}}$ \\
\hline 00-90-9 & + & + & + & +++ & ++ & $\mathrm{P}, \mathrm{K}^{\mathrm{c}, \mathrm{e}}$ \\
\hline 99-70-6B2 & + & + & + & +++ & ++ & $\mathrm{P}^{\mathrm{a}, \mathrm{b}, \mathrm{e}}$ \\
\hline $00-90-6$ & + & + & + & +++ & ++ & $\mathrm{P}^{\mathrm{d}}$ \\
\hline $00-90-7$ & + & + & + & +++ & ++ & $\mathrm{P}^{\mathrm{d}}$ \\
\hline $07-52-1$ & + & + & + & + & + & $\mathrm{G}^{\mathrm{a}}$ \\
\hline 99-79-Y & + & - & - & - & ++ & No \\
\hline $00-90-4$ & + & - & - & - & - & $\mathrm{P}^{\mathrm{d}}$ \\
\hline $07-162-2^{f}$ & + & - & - & - & - & \\
\hline 06-106-1 & + & - & - & - & - & $\mathrm{P}^{\mathrm{e}}$ \\
\hline $06-107-1$ & + & - & - & - & - & $\mathrm{P}^{\mathrm{d}, \mathrm{e}}$ \\
\hline $\begin{array}{l}{ }^{\mathrm{a}} \text { Toxigenic and } \\
{ }^{\mathrm{b}} \text { Similar or iden } \\
{ }^{\mathrm{c}} \text { Identical to is } \\
\text { (=00-90-1) fron } \\
\text { dInvasive vibrio } \\
\text { e Pathogenicity }\end{array}$ & $\begin{array}{l}\text { ive vibriosis } \\
\text { to diagnostic } \\
\text { associated } \\
\text { s et al. (2004) } \\
\text { nfirmed by h } \\
\text { mined in labo }\end{array}$ & $\begin{array}{l}\text { rmed by hi } \\
\text { tes from } 20 \\
\text { vibriosis, } \\
\text { gy challeng }\end{array}$ & $\begin{array}{l}2007 \text { (not sh } \\
\text { ning surface }\end{array}$ & ater source & solate $00-90$ & ntical with RE \\
\hline
\end{tabular}

(Holt et al. 1994, Estes et al. 2004) to verify their association with the genus Vibrio. A polyclonal antibody prepared as previously described (Elston et al. 1982) with confirmed specificity for a subset of Vibrio spp. was used to identify isolates as Vibrio spp. For initial screening and separation of nonvibrio isolates, bacteria were evaluated in a slide agglutination test. Positives were identified by a marked clumping and/or loss of motility in comparison to controls. The polyclonal antibody recognized a subset of variably pathogenic larval shellfish vibrios, including, but not limited to, Vibrio tubiashii. Strains were evaluated for proteolytic and hemolytic activity, as described by Hasegawa et al. (2008), using methods described by Halpern et al. (2003) and Chan \& Foster (1998). Proteolytic activity of the sterile, filtered $V$. tubiashii supernatants was assessed using azocasein; hemolytic activity was determined using sheep red blood cells.

Genetic characterization. Partial 16S rDNA sequences were determined to confirm association of the isolates with Vibrio spp., recognizing the limitation of this method for species characterization of vibrios (Thompson et al. 2006). Chromosomal DNAs of Vibrio spp. were isolated using a DNeasy Blood and Tissue kit (Qiagen). The 16S rDNA gene of Vibrio spp. isolates was amplified through PCR from these chromosomal DNAs, using 16S rDNA forward and reverse primers (5'-ATT GAA CGC TGG CGG CAG GCC TAA C-3' and 5'-GCA GCC CAC TCC CAT GGT GTG GCG G-3', respectively). The resulting PCR fragments were sequenced at the Oregon State University Center for Genome Research and Biocomputing core lab facility using the rDNA forward primer. To make a preliminary evaluation of phylogenetic relationships, the alignment of partial 16S rDNA gene sequences was made using ClustalW (Thompson et al. 1994). The sequence alignment was converted into the Molecular Evolutionary Genetics Analysis (MEGA) format in MEGA2.1 (www.megasoftware.net), and a phylogenetic tree was derived. The phylogeny, containing sequences from different organisms, was constructed by the neighbor-joining method.

Presence or absence of sequences coding for the Vibrio tubiashii protease and hemolysin was determined by standard PCR using $V$. tubiashii diagnostic primers 5'-ATG AAA CAA CGT CAA ATG CTT TG-3' (forward) and 5'-GAA CGG AGC ATC AGA AGC CCC AAG AGA-3' (reverse) for the protease (corresponding to the putative translational start site of 1 to 417 ), and $5^{\prime}$ TCA GCT ATA AGA ATG AAA AAA CAC-3' (forward) and 5'-GTA CGT GGA ATT GAC CAT CCT GTC-3' (reverse) for hemolysin (corresponding to the putative translational start site of 575 to 971). The Oregon State University Center for Genomic Research and Biocomputing website (http://bioinfo. cgrb.oregonstate. edu/) was used for DNA sequence analysis.

Pathogenicity of isolates. We tested the pathogenicity of several isolates in a replicated well-plate test using the approach of Estes et al. (2004) with Pacific oyster Crassostrea gigas larvae. In this study, however, 4 (instead of 1 ) target concentrations $\left(1 \times 10^{2}\right.$ to $1 \times$ $10^{5} \mathrm{cfu} \mathrm{ml}^{-1}$ ) of challenge isolate were tested in tripli- 
cate simultaneously, following initial range-finding testing, which spanned a broader dose range in some cases. Briefly, challenge bacteria were grown to stationary phase in Marine Broth shaker cultures and washed by centrifugation $\left(1400 \times g, 10 \mathrm{~min}, 10^{\circ} \mathrm{C}\right)$ in SSW. Based on a predetermined calibration curve, bacterial cell concentrations were estimated by measuring optical density at a wavelength of $623 \mathrm{~nm}$, and appropriately diluted and inoculated into the challenge suspension. Estimated bacterial cell concentrations were verified by plating bacterial suspensions in 10 -fold dilutions to determine actual final bacterial cell concentrations in the challenge suspensions.

Histology. The association of Vibrio spp. and particularly Vibrio tubiashii isolates with hatchery and nursery epizootics was documented by taking representative larvae and juvenile bivalve samples from the water column and tank bottoms of larval production systems. Larval samples were enumerated, measured, and photographed for apparently healthy, moribund, and dead animals under an Olympus BX-40 compound microscope equipped with an Olympus DP-71 digital camera and Olympus Microsuite 5 image analysis software, resulting in a numerical estimate of loss for each tank in each affected hatchery. Juvenile bivalves were similarly examined using either a compound microscope or stereoscope, depending on their size. Subsamples of the identical specimen group were cultured for bacteria and processed for plastic histology using the general method described by Elston et al. (1982). Selected bacterial isolates were tested to confirm pathogenicity using the 12-well plate method described by Estes et al. (2004), using Pacific oyster Crassostrea gigas larvae.

Production data. Production data were collected from 1997 to 2007 from a hatchery directly affected by the vibriosis outbreak. Due to changes in hatchery production, record keeping, and operations during the $10 \mathrm{yr}$ period, only the total production data for June to September 2005, 2006, and 2007 were considered sufficiently consistent for comparative analysis.

Sea surface temperature and upwelling data. SST data for the Netarts Bay (Oregon) hatchery was obtained from the NOAA online data for the Stonewall Banks NOAA buoy located $20 \mathrm{n}$ mile west of Newport, Oregon $\left(44.62^{\circ} \mathrm{N}, 124.53^{\circ} \mathrm{W}\right) 0.6 \mathrm{~m}$ below surface in $118.3 \mathrm{~m}$ depth (NOAA 2007a) for 1998 to 2007. Seawater temperature was measured in hatchery or bay locations using a calibrated thermometer. Upwelling data for 2005 to 2007 were obtained from the Pacific Fisheries Environmental Laboratory (NOAA 2007b). Degree days were calculated from average daily SST as the combined total ${ }^{\circ} \mathrm{C}$ above 0 .

Statistical evaluation. Data sets were compared using 2-tailed $t$-tests for unequal variance (Snedecor \& Cochran 1989).

\section{RESULTS}

\section{Reduction of hatchery productivity associated with vibriosis}

Because of changes in production and accounting methods, we only compared data from 2005 to 2007 for combined Pacific and Kumamoto oyster larvae production (Fig. 1). 2005 was considered a typical production year. 2006 had mildly reduced production due to a June and July outbreak of vibriosis, which resulted in low production reported for July $2006\left(0.895 \times 10^{9}\right.$ oyster larvae produced, compared with $1.13 \times 10^{9}$ in July 2005 and $1.03 \times 10^{9}$ in July 2007). Production was severely depressed in June, August, and September 2007, resulting in a total production for the June to August period of only $2.29 \times 10^{9}$ oyster larvae or $51 \%$ of the $4.48 \times 10^{9}$ larvae produced in 2005. For June to August 2006, a total of 4.46 $\times 10^{9}$ oyster larvae were produced. Although larval production in 2006 appears roughly equivalent to that of 2005 , production per unit of capacity was actually reduced in 2006 due to expansion ( $25 \%$ ) of tank production capacity between the 2005 and 2006 production seasons. Adjusting for this factor, production for 2006 and 2007 was thus only 80 and $41 \%$, respectively, of that expected based on 2005 production.

\section{Geographic distribution of Vibrio tubiashii and other larval and juvenile shellfish-pathogenic Vibrio spp.}

The source locations of the hatchery epizootics associated with isolation of Vibrio tubiashii and those confirmed by laboratory challenge are shown in Table 1. In addition, we isolated Vibrio spp. associated with larval and juvenile shellfish vibriosis in 2006 and 2007 from hatcheries and nurseries on the Gulf Coast of Florida, the west coast of North America near Los Mochis, Sinaloa, Mexico, and along the Pacific, including hatcheries and nurseries in the states of California, Oregon, and Washington. Pathogenic isolates were also obtained from the surface seawater supply line and a production facility at the Natural Energy Laboratory of Hawaii Authority (NELHA) site on Keahole Bay, Hawaii. We additionally isolated a pathogenic strain of Vibrio spp. associated with a precipitous loss of native oyster (Ostrea conchaphila) larvae from Willapa Bay (Washington) in August 2006 (A. Trimble pers. comm.).

\section{Bacteriological characterization}

Characteristics of selected isolates that were confirmed to be Vibrio spp. are shown in Table 2. Isolates consistent with being Vibrio tubiashii were found in 1998 


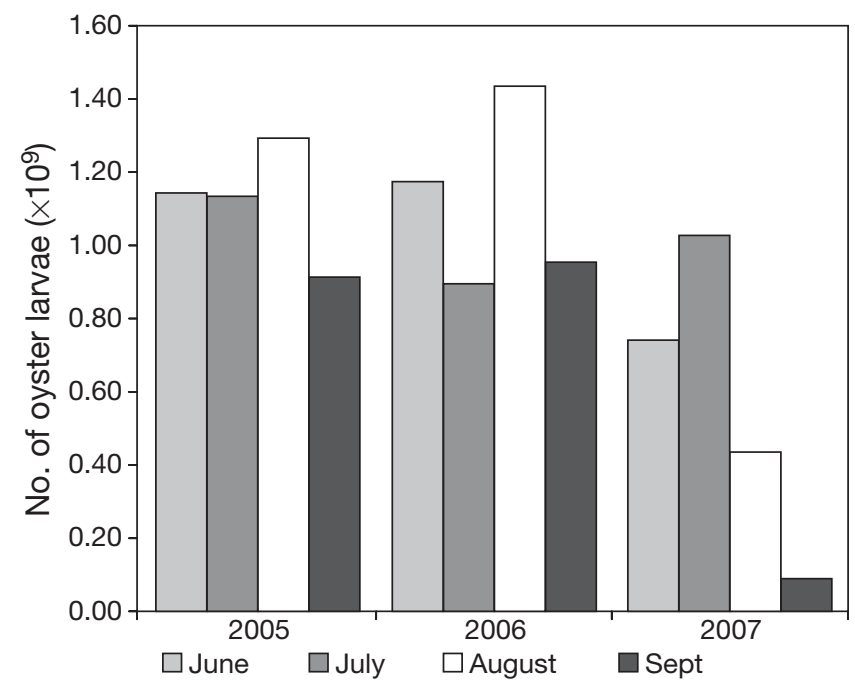

Fig. 1. Production of Pacific and Kumamoto oyster larvae from hatchery near Tillamook, Oregon for June to September 2005 to 2007. 2005 was considered a typical production year. The production declines in July 2006 and all months in 2007, compared with 2005 production, were attributed to infection of larvae by Vibrio tubiashii

and 1999 during and following an outbreak of vibriosis in a shellfish hatchery in Netarts Bay (Oregon), and isolated with increasing frequency in 2006 and 2007 from that location and also from the Hawaiian site in 2000. Fig. 2 shows that isolates from the most severely affected hatchery near Tillamook, Oregon (isolate num-

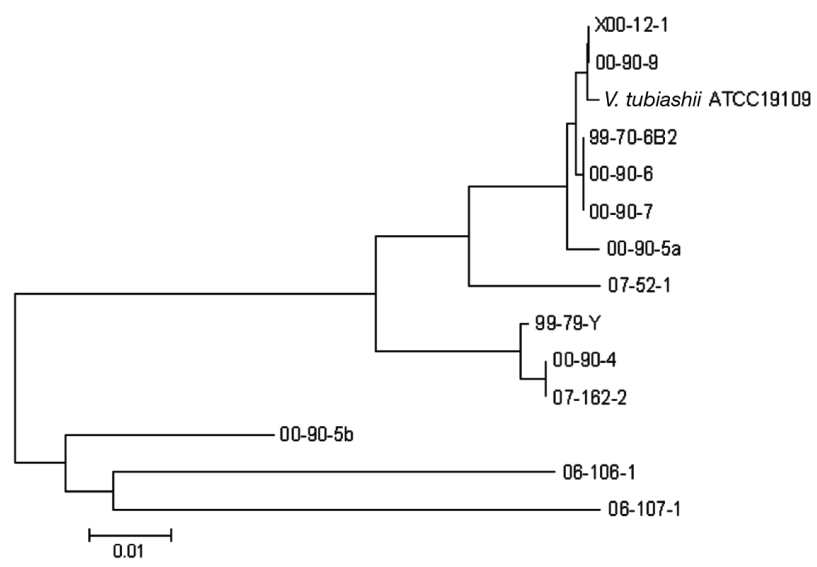

Fig. 2. Neighbor-joining phylogeny of partial sequences ( $\sim 560 \mathrm{bp})$ of $16 \mathrm{~S}$ rDNA gene from Vibrio spp. isolates. Scale bar is the estimated number of nucleotide changes per sequence position

Fig. 3. Laboratory challenge (\% survival) of Pacific oyster larvae with selected Vibrio spp. isolates: (a) isolate X00-12-1, (b) isolate 06-106-1, and (c) isolate 06-107-1. Four challenge doses were applied; larvae were evaluated in triplicate treatments at 6 intervals, as indicated on the $x$-axis. Results of the challenge-specific triplicate control group are shown in each challenge graph
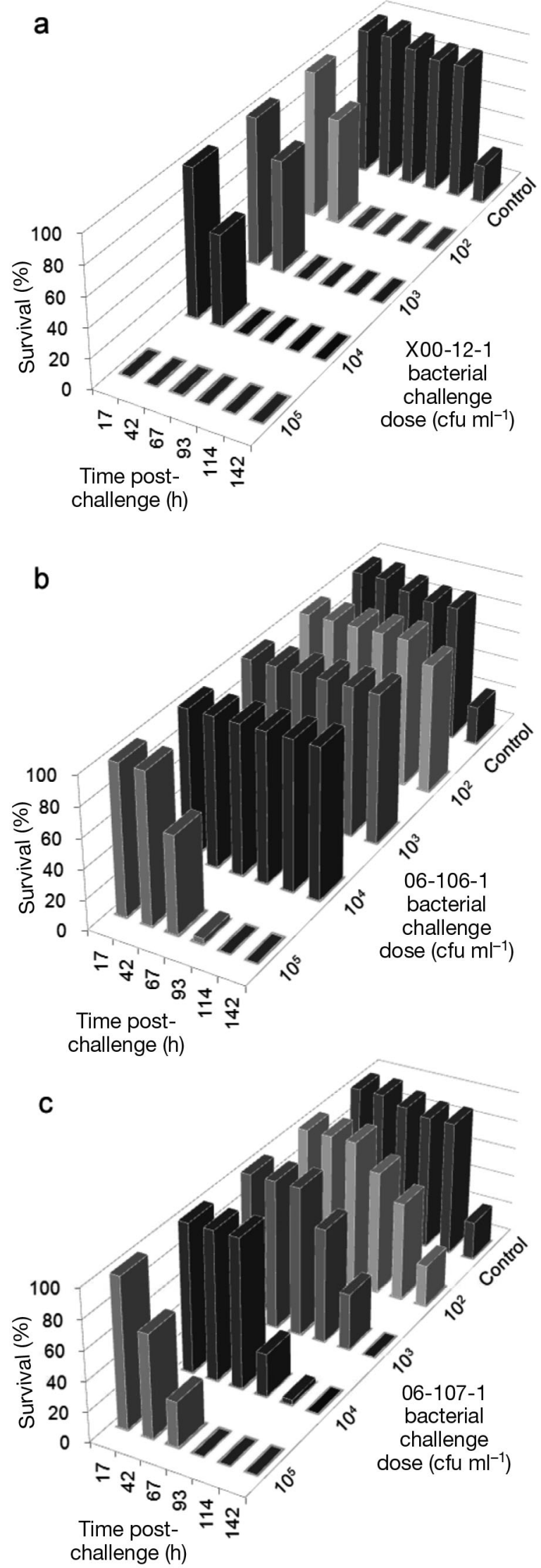
ber X00-12-1) and from the NELHA surface seawater system (isolate number 00-90-9) were most closely related to ATCC strain 19109 of $V$. tubiashii. These isolates were later determined to be highly pathogenic to shellfish larvae (Fig. 3). The degree of relatedness of other isolates described in this study is also shown in Fig. 2.

\section{Comparative pathogenicity and pathological manifestations}

Table 2 shows the association of Vibrio spp. and Vibrio tubiashii isolates with severe epizootics of larval and juvenile Pacific oyster, Kumamoto oysters, and geoduck clams. This association was confirmed by isolation and characterization of the pathogen and histological characterization of invasive and toxigenic vibriosis as described previously (Brown \& Losee 1978, Elston \& Leibovitz 1980, Brown 1981, Elston et al. 1981, Elston 1999), with examples shown later in this paper. Overall losses during epizootics are not easily quantified but can be approximated from hatchery data as well as detailed bacteriological and histological characterization of the typical disease process observed when vibriosis occurs.

Furthermore, we confirmed the pathogenicity of selected isolates in replicated laboratory well-plate and beaker assays. The results from a comparative pathogenicity trial are shown in Fig. 3. Isolate X00-12-1, confirmed to be a Vibrio tubiashii strain, was the most pathogenic in this controlled challenge experiment and resulted in $100 \%$ mortality in $<1 \mathrm{~d}$ at the highest concentration $\left(1 \times 10^{5} \mathrm{cfu} \mathrm{ml}^{-1}\right)$ and $<3 \mathrm{~d}$ at all other concentrations (Fig. 3). Isolate 00-90-9, also closely aligned with $V$. tubiashii, is also highly pathogenic, causing larvae to cease swimming and remain in a closed-shell condition within $20 \mathrm{~min}$ of administration of doses of $\sim 1 \times 10^{5} \mathrm{cfu}$ $\mathrm{ml}^{-1}$ and greater (data not shown).

In laboratory challenges, these isolates produced toxigenic effects on larvae that resulted in variable degrees of loss of velar cilia, exfoliation of velar epithelial cells, and failure to swim (Fig. 4). In commercial hatchery epizootics associated with similar Vibrio tubiashii isolates, larvae could survive low concentrations of exposure at an early stage for up to $2-3 \mathrm{wk}$, but manifested mild to moderate velar damage, loss of appetite, and death before metamorphosis. In such cases, we often observed focal bacterial abscesses in the mantle tissue, which appeared to be well-contained (Fig. 5). Toxigenic effects as well as invasive infections were observed in all ages of larvae from D-stage to metamorphosis and in bivalves both from laboratory challenge trials and from hatchery epizootics. Invasive infections were observed in juvenile oysters (Fig. 6) that were infected with Vibrio tubiashii and maintained in floating upwelling systems.
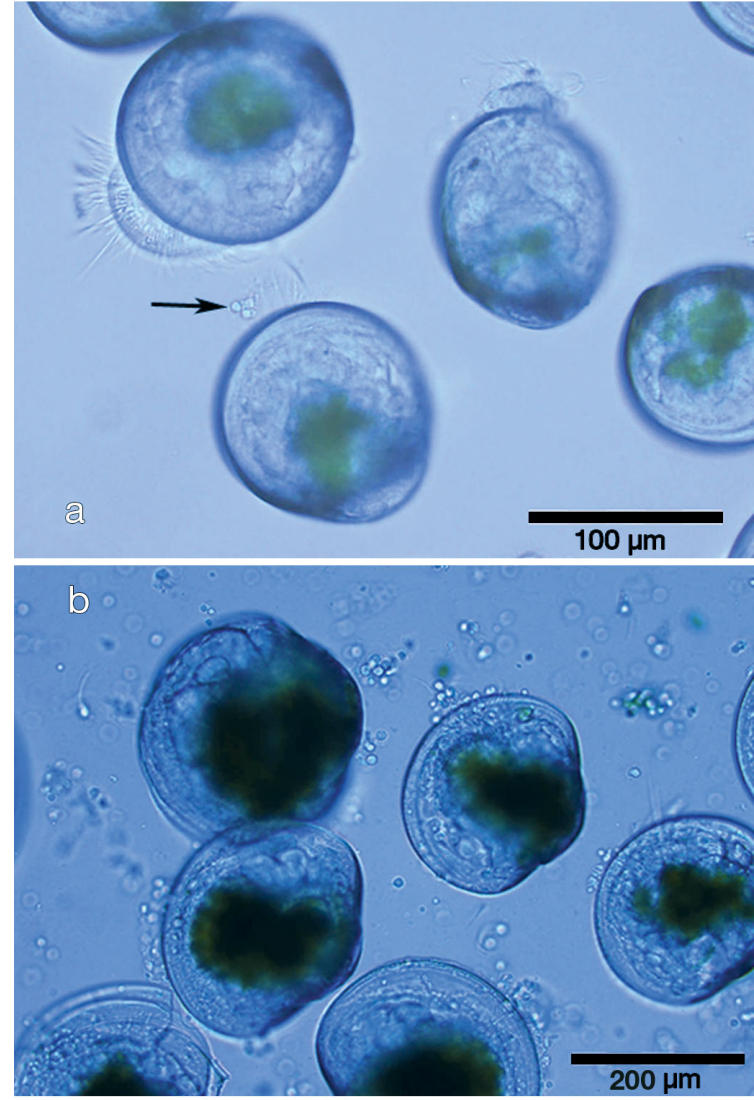

Fig. 4. Crassostrea gigas. (a) Early Pacific oyster veliger larvae showing toxigenic vibriosis, including deformed velums (top 2 larvae) and loss of individual velar cells (arrow). (b) Latestage veliger larvae showing the toxigenic effect of loss of velar cells at the valve periphery. In addition, these older larvae had invasive infections confirmed by histological examination

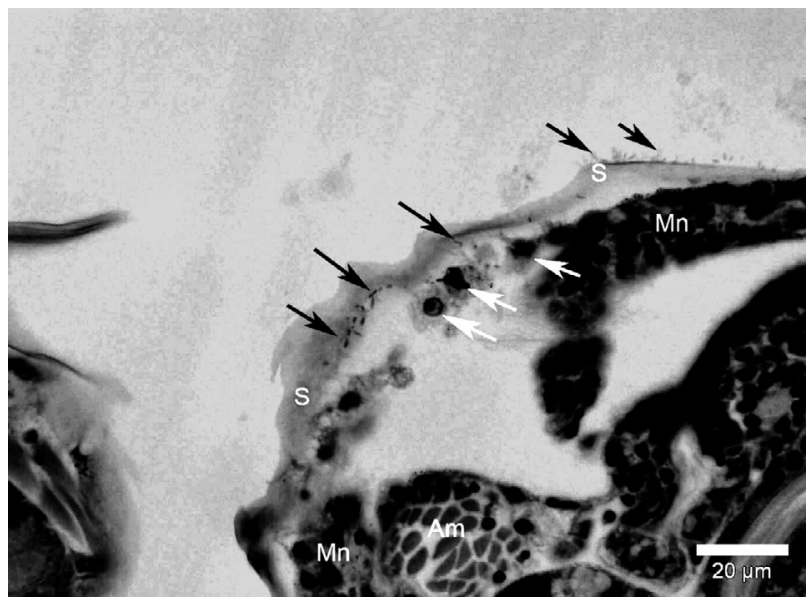

Fig. 5. Crassostrea gigas. Histological section of larvae showing a contained focus of bacterial infection, believed to be typical of chronic infection states. Bacterial cells are shown on the outside surface of the shell (S) (black arrows); necrotic or dying host mantle epithelial cells are shown in the abscess at the margin of the pallial cavity (white arrows). Mn, mantle; Am, adductor muscle 


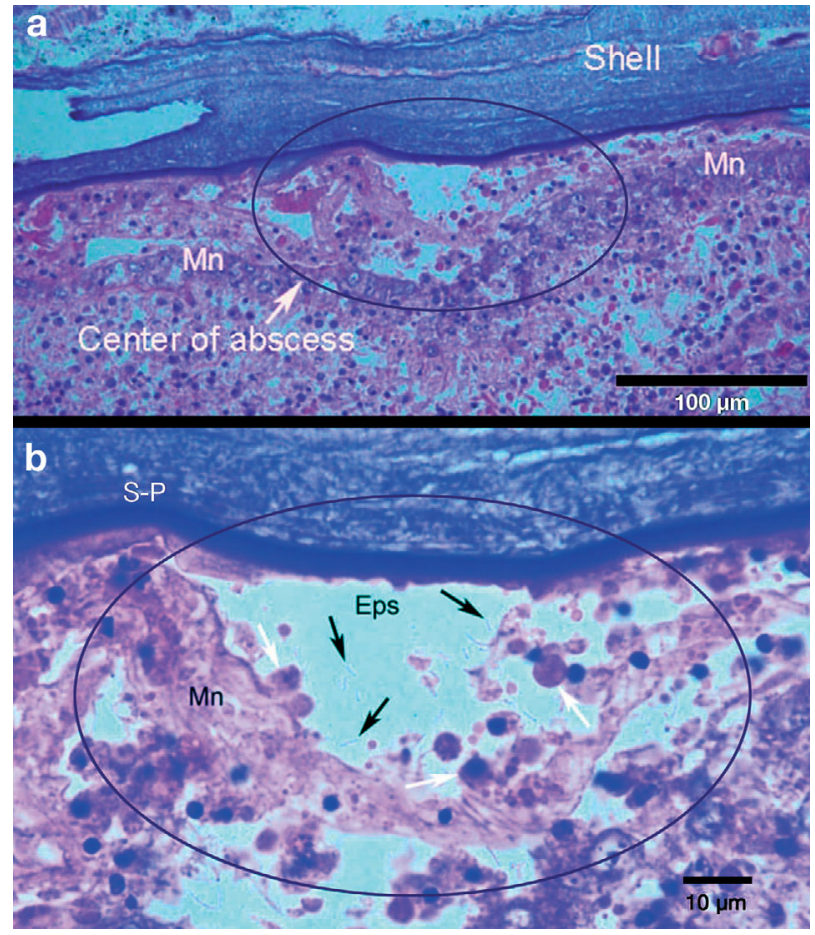

Fig. 6. Crassostrea gigas. Histological sections of a juvenile (shell length $\sim 8 \mathrm{~mm}$ ) showing contained bacterial abscess. (a) Lower magnification of abscess within the black oval outline showing its occurrence in the extra-pallial cavity, between the shell and mantle. (b) Higher magnification of the abscess showing individual bacterial cells (black arrows) and necrotic host mantle epithelial cells (white arrows). S-P,

shell periostracum; EpS, extra-pallial space; Mn, mantle

\section{Concentration and proportion of shellfish- pathogenic vibrios in seawater}

From ocean water, we found shellfish-pathogenic vibrios, including those closely aligned with Vibrio tubiashii, in concentrations up to $1.5 \times 10^{5} \mathrm{cfu} \mathrm{ml}^{-1}$. The concentration of such bacteria was particularly high along portions of the Oregon coast, compared with much lower seawater concentrations in samples from northern Hood Canal (Washington), or from surface seawater lines supplying the multi-user aquaculture facility located at Keahole Bay, Hawaii. Table 3 shows the concentration of the shellfish-pathogenic vibrios (based on polyclonal antibody reactivity) at flood and ebb tides from Netarts Bay (Oregon) $\sim 1 \mathrm{~km}$ from the mouth of the bay, over about 18 mo. The data are partitioned between samples obtained at water temperatures $>14^{\circ} \mathrm{C}$ versus those obtained at $<14^{\circ} \mathrm{C}$, including samples obtained during upwelling events in July and August when temperatures can drop as much as $5^{\circ} \mathrm{C}$ over $12 \mathrm{~h}$, usually to $10-13^{\circ} \mathrm{C}$. These data show that although vibrio concentrations are approximately equivalent or slightly higher in warmer water, the proportion of vibrios compared to total marine agar culturable bacteria in water during flood (incoming) tide is significantly greater $(p=0.025)$ in the cooler temperature range than in the warmer temperature range. This higher proportion of vibrios was typically found during intermittent cooler water periods with a positive upwelling index from late June through August. Remarkably, several samples showed pure colony isolation (24 h cultures on marine agar) of a strain consistent with V. tubiashii, at concentrations of $>10^{5} \mathrm{cfu} \mathrm{ml}^{-1}$ from flood-tide seawater at this location. Similarly, the proportion of shellfish-pathogenic vibrios isolated from ebb-tide seawater was slightly but not significantly higher ( $p=0.27$ ), in the cooler than in the warm temperature range (Table 3 ).

\section{Elevated sea surface temperature and Vibrio tubi- ashii outbreaks}

We first recorded a severe outbreak of vibriosis, for which the etiological agent was later confirmed to be toxigenic Vibrio tubiashii, in 1998 from a hatchery on Netarts Bay. The SST during this period was unusually elevated and remarkably similar to the elevated temperature regime observed in 2007, when severe vibriosis re-emerged (Fig. 7). The number of degree days calculated for SST between July 10 and August 21 was $\sim 23 \%$ greater $(\mathrm{p}<0.001)$ when evaluated by combining data for 1998 and 2007 and comparing it with 2005 and 2006 data. Degree days for this time period for 1998, 2005, 2006, and 2007 were 641, 540, 523, and 666 , respectively.

Table 3. Comparative concentrations and relative proportions of Vibrio spp. in incoming and outgoing Netarts Bay seawater from July 2006 to December 2007. Vibrio spp. subset determined by polyclonal antibody reaction in slide agglutination test. Table presents only rapidly growing colonies on marine agar (MA) as defined in 'Materials and methods'

\begin{tabular}{|c|c|c|c|c|c|}
\hline Range & $\begin{array}{l}\left({ }^{\circ} \mathrm{C}\right) \\
\text { Average }\end{array}$ & $\mathrm{n}$ & $\begin{array}{c}\text { MA } \\
\text { plate count }\end{array}$ & $\begin{array}{l}\text { Estim. Vibrio } \\
\text { spp. conc. }\end{array}$ & $\begin{array}{c}\text { Vibrio spp. } \\
\text { (\% total } \\
\text { colonies) }\end{array}$ \\
\hline \multicolumn{6}{|c|}{ Incoming tide } \\
\hline 9.6 to 13.9 & 11.84 & 17 & $6.37 \times 10^{4}$ & $2.74 \times 10^{4}$ & $47.6^{\mathrm{a}}$ \\
\hline 14.0 to 21.9 & 16.65 & 21 & $1.57 \times 10^{5}$ & $4.09 \times 10^{4}$ & 27.2 \\
\hline \multicolumn{6}{|c|}{ Outgoing tide } \\
\hline 9.6 to 13.9 & 12.01 & 21 & $4.29 \times 10^{4}$ & $2.91 \times 10^{4}$ & 34.1 \\
\hline 14.0 to 21.9 & 16.33 & 20 & $1.23 \times 10^{5}$ & $1.95 \times 10^{4}$ & 24.2 \\
\hline
\end{tabular}




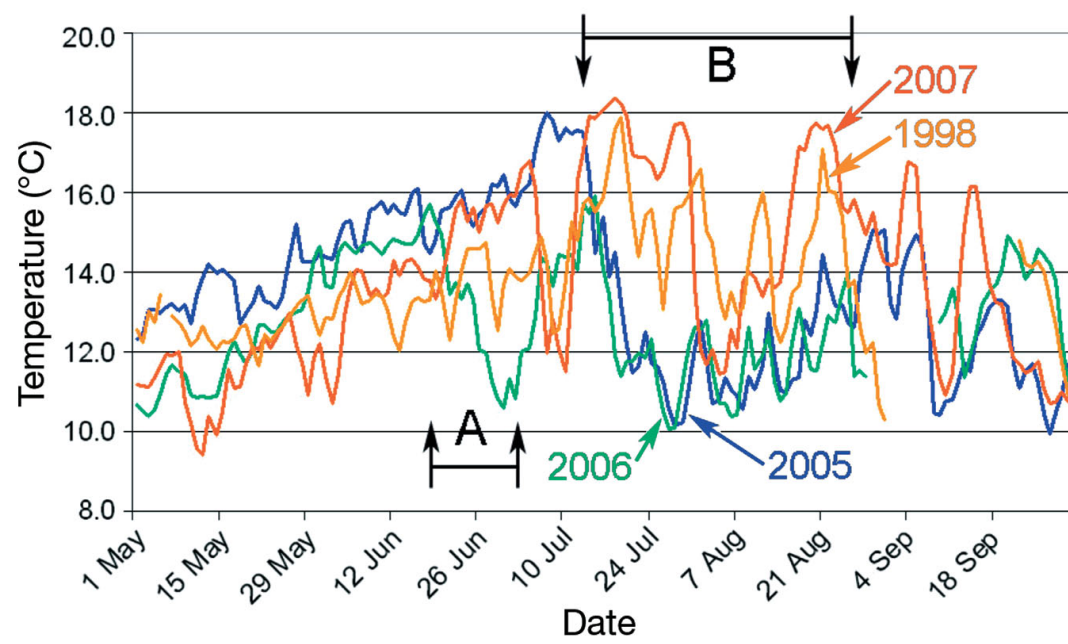

Fig. 7. Surface seawater temperature from May through September for 1998, 2005, 2006, and 2007. Data from the National Oceanic and Atmospheric Administration, US Department of Commerce Stonewall Banks buoy located $\sim 20 \mathrm{n}$ miles west of Newport, Oregon. (A) Time period of rapidly falling temperature in 2006 during which there was a transient outbreak of vibriosis at the Tillamook, Oregon hatchery. (B) Similar temperature profiles in 1998 and 2007 during which production dramatically dropped at the hatchery. Higher average temperature is evident during this period with oscillations caused by intermittent upwelling and intrusion of warmer-than-normal surface seawater. Note the extreme oscillations in temperature that continued into September 2007. Degree days were $\sim 23 \%$ greater $(p<0.001)$ for combined 1998 and 2007 data compared with 2005 and 2006 data for July 10 to August 21

corresponded with an early and severe outbreak of $V$. tubiashii vibriosis in hatchery-reared Pacific oyster larvae. This event was of shorter duration than that observed in 2007 and thus only moderately depressed the mid-season 2006 production of oyster larvae. In 2007, a strong but highly intermittent upwelling event occurred in mid to late July and August. The intervening periods were characterized by markedly elevated seawater temperatures (Fig. 7, bar B) and the apparent nearshore mixing of such elevated-temperature seawater with nutrient-rich upwelling waters.

\section{Hatchery locations and concentrations of Vibrio tubiashii}

The concentrations of shellfish-pathogenic Vibrio spp., including Vibrio tubiashii, in contaminated algal cultures, larval tank water, and broodstock holding water are shown in Table 4. Although larval tank water and broodstock water were often contaminated

The occurrence of vibriosis in hatchery-reared oyster larvae in 1998 also corresponded with strong intermittent upwelling from late July through August and the presence of a very strong El Niño (University of Illinois WW2010 Project, http://ww2010.atmos.uiuc.edu:80/ (Gh)/guides/mtr/eln/rcnt.rxml), which presumably mixed the warm surface seawater with the nutrientrich, upwelled deep seawater. In 2006, a strong upwelling event began on June 16 and lasted until about July 10 (Husby undated) (Fig. 7, bar A), during which we isolated pure cultures (based on marine agar growth for $6 \mathrm{~d}$ ) of Vibrio tubiashii from flood-tide seawater at concentrations up to $1.5 \times 10^{5} \mathrm{cfu} \mathrm{ml}^{-1}$. This with vibrios, higher concentrations were uniformly found in cultured algae.

Algal food culture contamination. Stock hatchery algal food flask line cultures, typically maintained in an isolation room, may remain aseptic for many months, but are also susceptible to contamination by dominant culturable strains of Vibrio tubiashii. Such cultures also occasionally contained nonvibrio contaminants. In many instances, we found stock algal cultures to be contaminated with apparent pure cultures (based on colony morphology) of either undescribed Vibrio spp. or V. tubiashii, with concentrations reaching as high as $2.01 \times 10^{6} \mathrm{cfu} \mathrm{ml}^{-1}$ in the following algal

Table 4. Concentration range of Vibrio spp. found in various stages of algal culture and other hatchery locations. Vibrio spp. subset determined by polyclonal antibody reaction in slide agglutination test. Table presents only rapidly growing colonies (48 $\mathrm{h}$ plate counts) on marine agar as defined in 'Materials and methods'

\begin{tabular}{|c|c|c|c|c|}
\hline \multirow[t]{2}{*}{ Sample type } & \multirow[t]{2}{*}{$\mathrm{n}$} & \multirow{2}{*}{$\begin{array}{c}\text { Vibrio spp. } \\
\text { (\% total colonies) }\end{array}$} & \multicolumn{2}{|c|}{ Vibrio spp. concentration $\left(\mathrm{cfu} \mathrm{ml}^{-1}\right)$} \\
\hline & & & Median & Max. observed \\
\hline Microalgal food stock cultures & 12 & 85 & $5.44 \times 10^{5}$ & $2.01 \times 10^{6}$ \\
\hline Microalgal food static carboy cultures & 6 & 83 & $3.52 \times 10^{5}$ & $6.72 \times 10^{5}$ \\
\hline Microalgal food vertical continuous-flow bag cultures & 38 & 49 & $2.60 \times 10^{4}$ & $1.32 \times 10^{6}$ \\
\hline Microalgal food horizontal continuous-flow bag cultures & 13 & 66 & $3.60 \times 10^{4}$ & $6.00 \times 10^{5}$ \\
\hline Microalgal food static tank cultures (20 to $25000 \mathrm{l}$ ) & 31 & 34 & $7.20 \times 10^{3}$ & $3.92 \times 10^{5}$ \\
\hline Larval tank water & 22 & 35 & $1.06 \times 10^{3}$ & $3.28 \times 10^{4}$ \\
\hline Geoduck clam broodstock water & 14 & 46 & $2.40 \times 10^{2}$ & $1.00 \times 10^{3}$ \\
\hline
\end{tabular}


stock culture food species: Thallasiosira pseudonana (3H), Skeletonema sp., Pavlova lutheri, Tahitian Isochrysis sp., Chaetoceros muelleri, and C. gracilis. There were no reports from the hatchery algologists that such contaminated cultures were performing poorly in terms of algal growth rate or culture appearance. Further, we observed no difference in growth performance and culture appearance between contaminated and uncontaminated algal cultures during short-term maintenance in the laboratory, although we did not investigate whether or not such contamination prevented algal cultures from achieving maximum potential density.

Expanded static algal-culture contamination: Staticor batch-cultured algae are typically transferred from a flask to a carboy, then to open tanks of progressively increasing volume. Microalgae in carboys are typically cultured for up to $72 \mathrm{~h}$. Carboy cultures of the same species reported for flask cultures were found contaminated with a maximum concentration of Vibrio spp., and in some cases, apparent pure cultures (marine agar) of Vibrio tubiashii of up to $6.72 \times 10^{5} \mathrm{cfu} \mathrm{ml}^{-1}$ and a median concentration of $3.52 \times 10^{5} \mathrm{cfu} \mathrm{ml}^{-1}$ (Table 4). Pathogens identified by antibody cross-reactivity as a sub-group of Vibrio spp. comprised, on average, 83\% of the total rapidly growing marine agar plate counts.

Expanded continuous-flow cultured algae: We examined continuous-flow, algal-culture systems as used in shellfish hatcheries (Helm et al. 2004), and characterized by a series of polyethylene or other types of bags, or carboys, configured for continuous-flow operation and linked by harvest lines. Results from the examination of these continuous-flow bag cultures, which may contain mixed algal species, from a contaminated hatchery showed an average $48 \mathrm{~h}$ marine agar bacterial growth composition of $49 \%$ vibrios from 38 vertical bag cultures with median and maximum observed concentrations of $2.60 \times 10^{4}$ and $1.32 \times 10^{6} \mathrm{cfu}$ $\mathrm{ml}^{-1}$. Horizontal bag cultures were found to have median and maximum concentrations of the pathogen of $3.60 \times 10^{4}$ and $6.00 \times 10^{5} \mathrm{cfu} \mathrm{ml}^{-1}$ (Table 4 ).
Contamination of hatchery air with shellfishpathogenic vibrios. Table 5 shows the results of air sampling for bacteria in hatcheries. Similar to the water samples, rapidly growing marine agar culturable bacteria in air were dominated by vibrios, including Vibrio tubiashii, in contaminated hatcheries. The concentration of bacteria was generally higher in more humid air, as expected, and also in air lines that contained visible moisture.

Sodium thiosulfate contamination. For static-batch algal cultures in hatcheries, sodium thiosulfate is routinely used to inactivate residual chlorine used to sterilize seawater. Sodium thiosulfate is prepared and stored as stock solutions typically ranging from $~ 100$ to $300 \mathrm{~g}$ $\mathrm{l}^{-1}(0.63$ to $1.98 \mathrm{M})$. Seawater treated with sodium hypochlorite and subsequently with sodium thiosulfate solution is expected to be sterile, at least immediately after treatment. Surprisingly, marine agar culture results from such treated seawater from one hatchery facility in March 2007 showed total $48 \mathrm{~h}$ marine agar counts of $2 \times 10^{2}$ to $3.6 \times 10^{2} \mathrm{cfu} \mathrm{ml}^{-1}$. In such samples, the proportion of colonies confirmed to be in the shellfish-pathogenic vibrio group (positive polyclonal antibody group) was 83 to $100 \%$ of the total count. Subsequent culture of the supply of stock thiosulfate from this facility, which had resided in a $225 \mathrm{l}$ drum for $\sim 3 \mathrm{mo}$, showed pure cultures of Vibrio tubiashii in the range of $9.84 \times 10^{4}$ to $1.20 \times 10^{5} \mathrm{cfu} \mathrm{ml}^{-1}$. Subsequent survey of other facilities and examination of newly prepared solutions of sodium thiosulfate as they aged showed widespread contamination of sodium thiosulfate stock solutions with V. tubiashii and other Vibrio spp. Stock solutions of sodium thiosulfate from 3 facilities had no marine agar culturable bacteria for up to $48 \mathrm{~h}$ after the solution was mixed. Solutions ranging in age from 1 to 3 wk had concentrations of $V$. tubiashii from 0 to $9.60 \times$ $10^{3} \mathrm{cfu} \mathrm{ml}^{-1}$. The pattern of contamination suggested heterogeneous contamination initially, followed by dominance of Vibrio spp. Thus, concentration of Vibrio spp. in stock cultures of thiosulfate increased with the age of the thiosulfate solution.

Table 5. Vibrio spp. concentrations in air supply and room air in hatcheries. Each bacterial concentration value is the average of 2 samples. Temperature and average \% relative humidity, 8 measurements over $2 \mathrm{~d}$. Air flow from each line system was estimated at $0.5 \mathrm{~m}^{3} \mathrm{~min}^{-1}$

\begin{tabular}{lccc}
\hline Sample type & $\begin{array}{c}\text { Vibrio spp. } \\
\left(\mathrm{cfu} \mathrm{min}{ }^{-1}\right)\end{array}$ & $\begin{array}{c}\text { Average relative } \\
\text { humidity }(\%)\end{array}$ & $\begin{array}{c}\text { Average } \\
\text { temperature }\left({ }^{\circ} \mathrm{C}\right)\end{array}$ \\
\hline Algae stock transfer room air, static plate & up to 0.3 & 65 & 23 \\
Algae carboy and small tank culture room, static plate & 6.7 & 65 & 23 \\
Air conditioner air flow in tank culture room & 36 & 77 & 23 \\
Tank room carboy air system, air flow & 234 & 77 & 20 \\
Tank room tank air system, air flow & $>2000$ & & 20 \\
Larvae air line, air flow & 1500 & & \\
\end{tabular}


Reduction of bacterial concentration due to water filtration. Comparison of seawater samples obtained prior to and after passing through hatchery multimedia filters with a nominal pore size of $\sim 50 \mu \mathrm{m}$, showed a reduction of Vibrio spp. of up to $10^{3}-10^{4} \mathrm{cfu} \mathrm{ml}^{-1}$.

\section{DISCUSSION}

\section{Geographic distribution of Vibrio tubiashii and re-emergence of vibriosis}

We document an economically significant reemergence of vibriosis in shellfish hatcheries and the occurrence of strains of bacteria closely aligned with Vibrio tubiashii and undescribed shellfish-pathogenic vibrios along the west coast of North America and from Hawaii. Our phylogenetic analysis revealed that newly isolated $V$. tubiashii strains, and more completely characterized strains including 99-70-6B2, X00-12-1, 00-90-6, 00-90-7, and 00-90-9 shared significantly high homology in the partial 16S rDNA sequence with known $V$. tubiashii strain ATCC19109 isolated from eastern oysters (>97\%; Fig. 2). Moreover, the PCR results of V. tubiashiispecific protease and hemolysin primers distinguished these $V$. tubiashii strains from other vibrio species (Table 2). These results clearly indicate the likely continuous presence of and a recent re-emergence of $V$. tubiashii along the west coast and many other locations.

Although there is no direct evidence that vibriosis is caused by the metalloprotease, Hasegawa et al. (2008) showed that the metalloprotease produced by Vibrio tubiashii acts as the major pathogenicity factor. In this study, newly identified $V$. tubiashii isolates also produced considerable levels of the extracellular protease and hemolysin, which correlated with high pathogenicity in a previous study by Estes et al. (2004) and in the present study.

On the other hand, other pathogenic Vibrio isolates, including 06-106-1 and 06-107-1, were clustered near each other in the phylogenetic tree, and were not closely clustered with Vibrio tubiashii. In addition, we failed to detect production of extracellular protease or hemolysin from both of these isolates. These results suggest that vibriosis caused by these isolates might be attributed to still unknown pathogenicity factors and that the mechanism of disease induction is more complex than currently understood.

Earlier reports (e.g. Hada et al. 1984, Macian et al. 2000, Du et al. 2002), in conjunction with the findings reported here, suggest that Vibrio tubiashii and other shellfish-pathogenic vibrios are cosmopolitan organisms in nearshore and possibly continental shelf seawater. We have established that the occurrence, distribution, and severity of this marine pathogen group and its impact on farmed and possibly on natural populations of bivalve shellfish can be greater and more persistent than previously recognized. The moderate outbreak of vibriosis in 2006 and the severe outbreaks in 1998 and 2007 appear linked to environmental conditions, specifically unusually warm SST. Clearly, more investigation is needed to better understand the climatic conditions that support blooms of pathogenic vibrios to help predict disease outbreaks, understand the impact of this pathogen on natural populations, and to prevent, manage, and mitigate the severe effects of the pathogen on coastal marine animal communities and shellfish production.

\section{Impact on intensive shellfish production and likely impact on natural populations}

The actual and potential impact of vibriosis on shellfish larval and seed production can be dramatic. One hatchery in our study estimated a 59\% loss in 2007 production attributed primarily to vibriosis. We also found high concentrations of Vibrio tubiashii to be associated with the disappearance of natural populations of native oysters (Ostrea conchaphila), but evaluation of the impact of vibriosis on natural populations, although likely significant, was beyond the scope of this study. Based on our results, additional study of vibriosis outbreaks on natural populations of marine organisms, particularly as they are related to warm seawater temperatures, is urgently needed.

The larval oyster production numbers presented from one hatchery underestimate the widespread impact of the vibriosis outbreak in cultured shellfish in 2007. The outbreak also occurred in other locations and other species, including losses of juvenile oysters up to $1 \mathrm{~cm}$ in shell length, which we documented from Baja California, California, Oregon, Washington, and Florida. Such seed losses from vibriosis were observed in both summer and winter 2007, probably due to infections carried into seed production facilities by larvae produced in 2006. The loss of larvae and juveniles as seed have a much greater economic impact through lost production of edible adult shellfish, which may not be realized for several years due to the absence of seed that would have matured to harvestable size.

Our investigation also suggests that early season losses (April to early June) may result from causes other than vibriosis. Such causes may include algal blooms and their degradation in the natural environment, although determination of specific causation is not possible without further investigation. Thus, further research is also needed on the various causes and remediation methods for shellfish hatchery losses and on the effect of changing environmental conditions on natural populations of marine biota. 


\section{Elevated sea surface temperature and intermittent upwelling facilitate outbreaks of vibriosis}

A marked similarity between 1998 and 2007 in terms of elevated July-August SST in the vicinity of our hatchery study in Netarts Bay, Oregon, is shown in Fig. 7 (bar B). This graph also shows that during this same period in 2005 and 2006, SST did not exhibit sustained elevation.

We postulate that the vibrio outbreaks are driven by the seeding of high concentrations of both shellfishpathogenic vibrios and nutrients in the nearshore environment as a result of upwelling, which occurs on a repetitive but intermittent basis during the upwelling season. This scenario, coupled with the mixing of elevated SST water during relaxation of upwelling, results in warming of the Vibrio spp.-seeded, nutrientrich waters, with consequent explosive growth of populations of Vibrio tubiashii and other similar rapidly growing bacteria.

Although the 2007 and possibly 1998 outbreaks appeared to have occurred through this mechanism, the shorter-term mid-June to early July 2006 vibriosis outbreak was likely driven by the seeding of the nearshore environment with high concentrations of Vibrio tubiashii during an upwelling event and the bloom of such bacteria within the heated seawater environment (22 to $26^{\circ} \mathrm{C}$ ) of the hatchery. Greater pathogenicity at 25 than at $20^{\circ} \mathrm{C}$ was reported in larvae of a related species, Crassostrea virginica, to strain RE22 (Table 1), and at 26 than at $20^{\circ} \mathrm{C}$ in our earlier report using C. gigas larvae, using various related pathogenic strains (Estes et al. 2004, Gómez-León et al. 2008).

Thus, the 2006 and 2007 events (Fig. 7, bars A \& B) represent 2 potential mechanisms by which hatchery vibriosis can result from environmental seeding linked to upwelling. In 2006, the $24 \mathrm{~d}$ episode of marked upwelling indicated by a progressive drop in SST (Fig. 7, bar A) resulted in seeding the hatchery intake with high concentrations of pathogenic Vibrio tubiashii, as documented in this study. Seawater warmed in the hatchery for rearing purposes facilitated an ongoing in-hatchery bloom in the vibrio-enriched incoming seawater. The second mechanism documented in 2007 resulted in a more severe episode of hatchery vibriosis. In this case, strong but intermittent upwelling events from mid to late July through August repeatedly enriched the Netarts Bay environment with pathogenic vibrios and upwelled nutrients. However, when upwelling relaxed, the intervening warm water (Fig. 7, bar B) presumably mixed with the nutrientrich, vibrio-enriched nearshore water causing the massive $V$. tubiashii blooms documented in Netarts Bay. Thus, the mechanism believed to be working in 2007 , and presumably in 1998, resulted in high concentra- tions of the shellfish-pathogenic vibrio in the natural waters of Netarts Bay, prior to the pumping of such waters into the hatchery. This condition caused a more intense and prolonged episode of vibriosis in the hatchery. The intermittent strong upwelling events continued into September in 2007 as evidenced by the magnitude of SST oscillation during this time period (Fig. 7), and may have continued to seed pathogenic vibrios into Netarts Bay through September 2007.

We do not know the ultimate source of the sometimes very high concentrations and pure to near-pure cultures observed for shellfish-pathogenic vibrios, occasionally including Vibrio tubiashii, and the relatively high proportion of Vibrio spp. in colder seawater, as documented in nearshore and Netarts Bay floodtide seawater (Table 3). However, our study indicated that upwelled water can be enriched with $V$. tubiashii. Since 2001, low or depleted oxygen conditions have been documented off the Oregon coast (Chan et al. 2008) and could contribute to the increased proportion of facultatively anaerobic bacteria, such as Vibrio spp. Furthermore, copepods which have been shown to be vectors of other Vibrio spp. (e.g. Colwell \& Huq 1999), are known to exhibit biomass peaks during August in this region (Hoof \& Peterson 2006). Whether copepods serve as a reservoir for shellfish-pathogenic vibrios is currently unknown.

Elevated ocean temperature in conjunction with intermittent upwelling appeared to drive the severe outbreaks of vibriosis observed in 1998 and in late July and August of 2007. A strong El Niño in 1997 and 1998 may have driven the measured elevation of SST in the summer of 1998 (Fig. 7), but it seems less likely that the much weaker El Niño reported for winter 2006-2007 would drive a similar measured elevation of SST from June to September 2007 (also shown in Fig. 7). It is important for management of coastal resurces to more fully understand the cause of such SST elevations.

Anecdotal references to poor production of oyster larvae in research and commercial production facilities along the Oregon coast correspond with upwelling events, typically during strong intermittent upwelling in August. Since the 1970s, hatchery operators have reported a phenomenon of 'August bad water' corresponding to such upwelling events, although apparently none have been as severe as those reported in 1998 and 2007.

\section{Need for further research}

Biology of marine vibrios. There is an urgent need to better understand the biology of shellfish-pathogenic vibrios to prevent or manage their effects in shellfish hatcheries and nurseries. Development of 
diagnostic techniques and targeted management strategies would be greatly facilitated by more complete characterization of known pathogenic strains, elucidation of additional virulence mechanisms, identification of genes associated with virulence, and a clearer understanding of strain relatedness and speciation. The latter, however, appears particularly challenging for the vibrios (Thompson et al. 2006). It would also be extremely beneficial to understand the composition and evolution of hatchery communities of bacteria in various environments. Through such basic research, rational approaches for the prevention of vibriosis by water treatment, removal of bacteria or their toxins, and displacement of bacteria by benign or beneficial bacteria can be pursued more effectively. Until such basic knowledge is expanded, it will be difficult to consistently predict or manage vibriosis and ultimately prevent its occurrence in shellfish hatcheries and nurseries.

Oceanographic research. Based on our reported findings and the suggested hypotheses, detailed oceanographic research is urgently needed to explain and predict the relationship of the occurrence, distribution, and concentration of Vibrio tubiashii and other shellfish-pathogenic Vibrio spp. to (1) elevated SST and its intrusion into nearshore areas, (2) the mixing of cold, upwelled water and warm surface seawater in nearshore areas, and (3) the extent of oxygen-depleted waters as sources of facultatively anaerobic bacteria. Ultimately, this understanding will help determine the environmental source and driving factors for the moderate to high concentration of $V$. tubiashii and other Vibrio spp. in nearshore seawater that have the capacity, at least at high concentrations, to be destructive to early-life-stage marine organisms.

\section{Previously unreported host species and relative host susceptibility}

In this paper, we extended the host range of Vibrio tubiashii to include hatchery-reared Pacific oysters Crassostrea gigas, Kumamoto oysters C. sikamea, and geoduck clams Panope abrupta. Although further comparative studies on susceptibility would be useful, the hatchery data strongly suggest differential susceptibility of various species of bivalve shellfish. For example, geoduck clam larvae, as well as Pacific and Kumamoto oysters, appear to be highly sensitive to vibrio infection, whereas Manila clams are relatively resistant. During our studies of outbreaks of Pacific oyster vibriosis, mussel Mytilus galloprovincialis larvae were simultaneously cultured without any reported morbidity or mortality.

\section{Dose, pathogenicity, and pathogenesis}

The pathogenicity dose curves generated in smallscale laboratory challenge experiments, as we used and as reported previously (Estes et al. 2004), may not necessarily represent the same dose-disease relationship in large-scale bivalve hatchery production. Generally, our results indicate that lower concentrations can cause morbidity and mortality in laboratory microcosms than are required to cause outbreaks in production facilities. However, it is important to test suspect pathogens at a range of doses in challenge experiments, including relatively low doses.

The induction of the disease process remains poorly understood. As observed, when very early-stage larvae ( 0 to $48 \mathrm{~h}$ post fertilization) are exposed to low concentrations of bacteria, and presumably to bacterial exotoxins, developmental anomalies are induced and growth is stunted; although such larvae may survive for many days, few survive through metamorphosis. This observation from hatchery-produced larvae is supported by the additional observation that $2 \mathrm{~d}$-old Pacific oyster larvae from a non Vibrio tubiashii-infected hatchery were successfully raised under low to moderately contaminated conditions, whereas fertilized eggs at the contaminated hatchery cannot be raised successfully through metamorphosis (S. Cudd pers. comm.).

Although it has been reported that gastrointestinal mucus induces production of the metalloprotease in the fish pathogen Vibrio anguillarum (Denkin \& Nelson 1999), the factors that induce the production of the known protease or cytolysin in some strains of Vibrio tubiashii and other shellfish-pathogenic vibrios are still unknown. In this study, $V$. tubiashii strains such as 0090-6, 00-90-9, and X00-12-1 were capable of producing considerable levels of protease as well as hemolysin in $\mathrm{LB} 1 \% \mathrm{NaCl}$ medium. In a variety of marine vibrio species, these exoproteins are controlled by a growth phase-dependent regulatory system (quorum sensing) (Milton 2006). Our previous study also showed that production of the metalloprotease and hemolysin in $V$. tubiashii are growth-dependent (Hasegawa et al. 2008). We have initiated studies to clarify what inducible signals are responsible for production of exoproteins in $V$. tubiashii. Furthermore, there may be additional unknown toxigenic molecules produced by these pathogenic strains of bacteria. The presence and pathogenic effect of extracellular products prepared from strains of $V$. tubiashii has been previously demonstrated (Estes et al. 2004). We demonstrated lesions in young larvae ( 0 to $48 \mathrm{~h}$ post fertilization) that are toxigenic and unrelated to invasive infections. Clearly, there may be metabolic and developmental damage in such young larvae not directly manifested in structural alterations in the tissues. 
Invasive infections may occur in all ages of larvae and in juvenile mollusks. In this study, we present, for the first time, evidence for invasive infections and extensive mortality in farmed juvenile oysters (shell length up to 8-10 $\mathrm{mm}$ ) directly linked to Vibrio tubiashii infection. The pathogenesis is similar, if not identical, to that reported in various earlier papers on undefined species causing vibriosis or other bacterial infections in larval and juvenile mollusks (Elston \& Leibovitz 1980, Elston et al. 1981, 1999, Elston 1999). In these infections, the pathogen adheres to the external and internal shell surfaces, gaining entry by growing along the shell margin and into the pallial cavity. Subsequently, the bacteria invade the subpallial space with associated mantle necrosis, and finally invade the coelomic cavity. The invasive infections in farmed juvenile oysters were often associated with overcrowding and/or poor water circulation in production facilities. Such infections appeared to be chronic in affected juveniles but a toxigenic effect on juvenile bivalves cannot be discounted and this possibility merits further investigation.

To understand the nature and causal factors of disease outbreaks, each outbreak should be systematically categorized by the type of infection and detailed nature of lesions observed. Interestingly, the histological examinations made in this study indicate that vibriosis in both larval and juvenile oysters can be chronic in the form of contained abscesses in the mantle tissue. Although such chronic abscesses may not lead to nearterm mortality, they are likely to reduce growth and overall health, and result in ultimate failure of production. Gómez-León et al. (2008) showed that in the closely related species Crassostrea virginica, susceptibility to Vibrio tubiashii (strain RE22, Table 1) decreased with age when early-stage larvae and juveniles were compared.

\section{Impact and management of hatchery algal-culture contamination}

Persistent contamination of various components of shellfish hatcheries and nurseries may contribute to the chronic occurrence of vibriosis in such facilities. Because such pathogen contamination is an uncontrolled variable, it is not surprising that production from such facilities is highly variable and unpredictable. We identified several areas of persistent contamination (Tables 4 \& 5) that can be eliminated by management steps.

Algal-culture contamination is perhaps the most insidious of the various forms of contamination. We found concentrations of pure to near-pure culture of Vibrio tubiashii and other Vibrio spp. in stock, and expanded static and continuous-flow algal cultures at typical concentrations $>10^{5} \mathrm{cfu} \mathrm{ml}^{-1}$. Shellfish-pathogenic vibrio contamination results in 2 problems for larval culture. First, the pathogens can replicate to high concentrations over a number of days during expansion of the algal cultures, with the bacteria possibly reaching a stationary growth phase. Secondly, such contamination can persist in either stock or continuous algal cultures for long periods. At a hatchery in Washington State, we discovered high concentrations of $V$. tubiashii in hatchery-bag (continuous) cultures in the winter of 2007, 4 mo after nondetection of contamination in influent hatchery seawater. We also determined that several algal species commonly used in bivalve hatcheries can co-exist with pathogenic $V$. tubiashii without apparent effects on algal growth rate or maximum density, although the detailed dynamics of this interaction merit further investigation. Keeping stock algal cultures free of bacterial pathogen contamination is theoretically a relatively simple process. The cultures, which are usually transferred using aseptic techniques, should periodically be cultured and tested for contamination. Low-volume expansion cultures that are closed should be provided with submicron-filtered dry air. Thus, closed-flask cultures and low-volume expansion cultures can be maintained contamination free. Periodic monitoring should be conducted using either marine agar plate counts or growth in marine broth. Use of marine broth is both quick and inexpensive, but will not distinguish between typical benign contaminants and those that may actually stimulate algal growth and suspect pathogens.

Expanded algal cultures that are contaminated with pathogenic vibrios and are used as food for larval and juvenile bivalves can be a means of continuous introduction of the pathogens and their exotoxins to the cultured animals. This may significantly impact larval culture success if the pathogenic vibrios or toxins produced in such cultures are at relatively high concentrations, despite the dilution that occurs when the food culture is added to the larval cultures. A typical contaminated algal culture may contain $5 \times 10^{5} \mathrm{cfu}$ of pathogenic vibrios $\mathrm{ml}^{-1}$. Even if this is diluted $1000 \times$ or more upon introduction to the larval or juvenile culture tanks, it provides a continuous, low-level inoculation of such cultures, which are often a rich substrate for bacterial growth. Thus, it is not surprising that hatcheries and nurseries with pathogen-contaminated algal stocks operate with variable unpredictable results and apparently far below capacity.

Preventing contamination of open static algal tanks in a moist environment with detectable concentration of airborne vibrios, including Vibrio tubiashii, may not be possible. However, pathogen contamination of such cultures can be minimized by (1) introducing bacteria- 
free air, often used in hatcheries for mixing algae, (2) improving water disinfection and treatment systems, (3) maintaining pathogen-free status of starter and expanded cultures to as high a volume as feasible, (4) ensuring that excess nutrients are not added to the algal cultures, and (5) either using contaminant-free sodium thiosulfate or preferably, an alternative means of seawater disinfection to avoid any preferential growth enhancement of pathogenic vibrios in contaminated sodium thiosulfate. In addition, high-quality feed with the lowest probability or degree of contamination should be fed to the youngest stages of sensitive species. A system of bacterial monitoring of such algal tanks should be implemented to determine the presence and concentration of pathogen contamination. Current experiments indicate that benign or beneficial bacteria can exclude or reduce the degree of contamination in algal cultures (R. A. Elston unpubl. data); addition of such bacteria may provide an additional means of controlling contamination.

Contamination of closed-bag, continuous algal cultures with shellfish-pathogenic vibrios can also result in persistent contamination of larval and juvenile feed with toxigenic and invasive pathogenic species. We observed several methods that can reduce or at least limit such contamination, including constructing bags in relatively small harvest modules so that the algalfood harvest-line network serves a limited number of bags. We also found that disinfection of the bag systems by steam sterilization, as practiced in hatcheries, does not always result in thorough sterilization. Although the continuous bag algal-culture system has been extremely useful for the production of high concentrations of high-quality microalgal food, the system, as routinely operated, is not working at its maximum potential and often serves as a means of continuous introduction of bacterial pathogens and toxins to cultured larval and juvenile shellfish. Ultimately, it may be necessary to provide separate clean greenhouses for hatcheries, instead of cultivating microalgal food in animal rearing rooms.

\section{Sodium thiosulfate contamination in hatcheries}

The discovery of low to moderate concentrations of Vibrio tubiashii in seawater that had been subjected to treatment with sodium hypochlorite followed by neutralization of excess chlorine with sodium thiosulfate was initially surprising. We traced this finding to contaminated bulk batches of sodium thiosulfate. These 2251 batches of thiosulfate were made approximately every 3 mo and used daily in a disinfection procedure for seawater to be used in batch algal cultures. The bulk sodium thiosulfate contamination at times ap- peared to consist of pure cultures of a vibrio, based on colony morphology on $48 \mathrm{~h}$ marine agar cultures, as well as examination of bacterial cell morphology and polyclonal antibody testing of bacteria from a subset of colonies. This vibrio contamination including, in some cases, shellfish-pathogenic $V$. tubiashii, resulted in concentrations as high as $1.2 \times 10^{5}$ cfu of the pathogen $\mathrm{ml}^{-1}$ of the bulk material, which was subsequently and ironically introduced into the disinfected seawater. Brown (1990) and Tuttle et al. (1974) noted that thiosulfate can stimulate the growth of some marine bacteria, including shellfish-pathogenic vibrios, and that such stimulated bacteria would persist longer in a stationary phase. Our results suggest that the pathogenic vibrios we describe here are clearly exhibiting this phenomenon. We found that pure colonies of $V$. tubiashii would appear in stock thiosulfate as early as $2 \mathrm{~d}$ after preparation from a solid concentrate. Thus, if stock thiosulfate is made only in batches sufficient for 1 or $2 \mathrm{~d}$ use and $V$. tubiashii becomes introduced into the material, the concentration will remain low, and the bacterial culture will most likely not reach log phase. Low numbers of V. tubiashii cells will likely be destroyed when the thiosulfate solution is added to the chlorinated seawater, whereas high concentrations of vibrios may result in a small percentage of the pathogen surviving the dechlorination process, thus seeding the new algal cultures. Elimination of the long-term storage of sodium thiosulfate effectively eliminated this source of pathogen contamination of sterilized seawater.

\section{Broodstock contamination}

Our studies confirmed results of earlier studies (e.g. Lodeiros et al. 1987, Sainz-Hernández \& MaedaMartínez 2005) that broodstock, as would be expected, can be a source of bacterial pathogen contamination. However, we did not conduct a detailed study of broodstock contamination.

\section{Water treatment}

We did not conduct a comprehensive examination of water-treatment systems in this study. However, our seawater and hatchery bacteriological monitoring program indicated that sand and multimedia filters can reduce bacterial contamination, including that by shellfish-pathogenic bacteria. This is presumably due to stickiness of the bacterial cells and their adhesion to filter components, media, and debris in the filter. Efficacy of this process is obviously very dependent on the particular system used and the adequacy of system maintenance, with a demonstrated potential reduction 
in bacterial contamination by up to a factor of $10^{4}$, but actual reduction often by a factor of $10^{2}$ or less (data not shown). Although bacterial cells may be captured within the filter and form biofilms in various parts of the system, toxins that may be generated may also be released into the hatchery system. The dynamics of interaction of pathogenic bacteria with filter systems needs further investigation. In the meantime, monitoring filter output for pathogenic bacteria and backflushing filters with filtered rather than raw seawater to reduce the mass of entrained pathogenic bacteria may be important for hatchery water management.

Additional means of water treatment are needed at certain locations, such as at the NELHA site from which we consistently isolated extremely pathogenic strains highly similar to Vibrio tubiashii. Each location should be assessed in terms of specific water-treatment requirements, and detailed evaluation of water-treatment methods is an area for further research and development.

\section{Preventing contamination of pumped-air systems}

Moisture in air or in pressurized-air lines increases the probability of aerosolization of pathogenic bacteria and formation of colonies in water accumulations. Contamination-free cultivation of algae in closed systems within a moist hatchery environment is bound to be challenging. Remediation can take several forms. The algal systems can be placed in a separate greenhouse with dried air, positive dried sterilized air pressure, and with only limited entry allowed. In addition, tightening seals on closed culture bags or other containers and ensuring that aseptic methods are used for the introduction of algal starts or other materials to the culture systems will reduce the chances of contamination by pathogens. Although some species of microalgae perform better with bacterial contaminants than others, such contaminants should obviously not be pathogenic to shellfish larvae or seed. Intentional seeding with bacteria of benign strains that displace or outcompete pathogenic strains has shown success in early trials. Provision of pressurized air for mixing of the closed systems may provide increased surface area (on air bubbles) for the growth of bacteria, although this method is commonly used in commercial applications. Such air pumped through a carbon-vein pump is usually heated, facilitating drying of the air. However, air lines should be monitored for the accumulation of moisture, which must be eliminated if it accumulates. Submicron filters can be used on air-line inputs to algal cultures but are only useful and cost efficient if the air supplied to the filters is relatively dry. Wet filters will degrade quickly. Thus, the ideal situation is to provide dry air that passes a submicron filter just prior to introduction to the algal-culture system.

\section{Environmental contribution to vibriosis outbreaks}

Vibriosis, including that caused by Vibrio tubiashii, requires a variety of environmental conditions, both in nature and in intensive hatcheries and nurseries, to cause disease. Elevated temperature is clearly one condition that can facilitate outbreaks of vibriosis. However, other conditions related to poor larval or juvenile nutrition, suboptimal $\mathrm{pH}$ resulting from a variety of factors, oxygen tension, and toxic degradation products from algal blooms or marine biota may also provide conditions conducive to outbreaks of vibriosis. In intensive hatcheries and some natural environments, depletion of essential trace minerals may also contribute to suboptimal health and thus to disease outbreaks. Water-treatment systems may remove both pathogenic bacteria and such essential trace elements. Thus, to make progress towards improving the health of farmed and natural populations of marine organisms, we should recognize that although vibriosis may be an ultimate morbidity and mortality factor, the presence of such pathogenic bacteria usually requires exacerbating conditions to cause a disease outbreak.

Acknowledgements. We thank S. Giovannini for many helpful discussions and E. J. Lind for excellent technical assistance. This research was partly supported by the US Department of Agriculture Small Business Innovation Research (SBIR) grant award number 2004-33610-14750 to AquaTechnics and by NIH grant AI-063121-02 to C.C.H.

\section{LITERATURE CITED}

Brown C (1973) The effects of some selected bacteria on embryos and larvae of the American oyster Crassostrea virginica. J Invertebr Pathol 21:215-233

Brown C (1981) A study of two shellfish-pathogenic Vibrio strains isolated from a Long Island hatchery during a recent outbreak of disease. J Shellfish Res 1:83-87

> Brown C (1990) Nutritional requirements for extracellular accumulation of toxin produced by a pathogenic Vibrio sp. J Fish Dis 13:239-243

Brown C, Losee E (1978) Observations on natural and induced epizootics of vibriosis in Crassostrea virginica larvae. J Invertebr Pathol 31:41-47

> Chan PF, Foster SJ (1998) Role of SarA in virulence determinant production and environmental signal transduction in Staphylococcus aureus. J Bacteriol 180:6232-6241

Chan F, Barth JA, Lubchenco J, Kirincich A, Weeks H, Peterson WT, Menge BA (2008) Emergence of anoxia in the California Current large marine ecosystem. Science 319:920

Colwell RR, Huq A (1999) Global microbial ecology: biogeography and diversity of vibrios as a model. J Appl Microbiol 85(Suppl 1):134S-137S 
Delston RB, Kothary MH, Shangraw KA, Tall DB (2003) Isolation and characterization of zinc-containing metalloprotease expressed by Vibrio tubiashii. Can J Microbiol 49:525-529

Denkin SM, Nelson DR (1999) Induction of protease activity in Vibrio anguillarum by gastrointestinal mucus. Appl Environ Microbiol 65:3555-3560

Du Z, Wang P, Li J, Robertson P, Austin B (2002) Isolation and identification of two bacteria producing agarase. Mar Sci Haiyang Kexue 26:1-4

Elston RA (1984) Prevention and management of infectious diseases in intensive mollusc husbandry. J World Maric Soc 15:284-300

Elston RA (1999) Development, histology and health management of seed oysters. World Aquaculture Society, Baton Rouge, LA, p 110

Elston R, Leibovitz L (1980) Experimental vibriosis in larval American oysters, Crassostrea virginica. Can J Fish Aquat Sci 37:964-978

Elston R, Leibovitz L, Relyea D, Zatila J (1981) Diagnosis of vibriosis in a commercial oyster hatchery epizootic, a case history. Aquaculture 24:53-62

Elston RA, Elliott E, Colwell RR (1982) Conchiolin infection and surface coating Vibrio: shell fragility, growth depression and mortalities in cultured oysters and clams (Crassostrea virginica, Ostrea edulis and Mercenaria mercenaria). J Fish Dis 5:265-284

Elston RA, Frelier PF, Cheney D (1999) Extrapallial abscesses associated with chronic bacterial infections in the intensively cultured juvenile Pacific oyster Crassostrea gigas. Dis Aquat Org 37:115-120

Estes RM (2002) Characterization of pathogenic and non-pathogenic bacteria associated with bivalve mollusc larvae and shellfish hatcheries in the Pacific Northwest and Hawaii. MSc thesis, University of Washington, Seattle, WA

Estes RM, Friedman CS, Elston RA, Herwig RP (2004) Pathogenicity testing of shellfish hatchery bacterial isolates on Pacific oyster Crassostrea gigas larvae. Dis Aquat Org 58: 223-230

- Gómez-León J, Villamil L, Salger SA, Sallum RH, RemachaTriviño A, Leavitt DF, Gómez-Chiarri M (2008) Survival of eastern oysters Crassostrea virginica from three lines following experimental challenge with bacterial pathogens. Dis Aquat Org 79:95-105

Hada HS, West PA, Lee JV, Stemmler J, Colwell RR (1984) Vibrio tubiashii sp. nov., a pathogen of bivalve mollusks. Int J Syst Bacteriol 34:1-4

Halpern M, Gancz H, Kashi Y (2003) Vibrio cholerae hemagglutinin/protease degrades chironomid egg masses. Appl Environ Microbiol 69:4200-4204

Hasegawa H, Lind EJ, Boin MA, Häse CC (2008) The extracellular metalloprotease of Vibrio tubiashii is a major virulence factor for Pacific oyster (Crassostrea gigas) larvae. Appl Environ Microbiol 74:4101-4110

Helm MM, Bourne N, Lovatelli A (2004) Hatchery culture of bivalves, a practical manual. FAO Fisheries Technical Paper 471. Food and Agriculture Organization of the United Nations, Rome

Editorial responsibility: Eugene Burreson,

Gloucester Point, Virginia, USA
Holt JG, Kreig NR, Sneath PH, Staley JT, Williams ST (1994) Bergy's manual of determinative bacteriology. Williams \& Wilkins, Baltimore, MD

Hoof RC, Peterson WT (2006) Copepod biodiversity as an indicator of changes in ocean and climate conditions of the northern California Current ecosystem. Limnol Oceanogr 51:2607-2620

Husby DM (Undated) West Coast upwelling indices data files. http://mercury.ornl.gov/metadata/nbii/html/ nbii/www.nbii.gov_metadata_mdata_NOAA_noaanmfs 0028.html

Kothary MH, Delston RB, Curtis SK, McCardell BA, Tall BD (2001) Purification and characterization of a vulnificolysinlike cytolysin produced by Vibrio tubiashii. Appl Environ Microbiol 67:3707-3711

> Lodeiros C, Bolinches J, Dopanzo CP, Toranzo AE (1987) Bacillary necrosis in hatcheries of Ostrea edulis in Spain. Aquaculture 65:15-29

Macian MC, Garay E, Gonzalez-Candelas F, Pujalte MJ, Aznar R (2000) Ribotyping of Vibrio populations associated with cultured oysters (Ostrea edulis). Syst Appl Microbiol 23:409-417

Milton DL (2006) Quorum sensing in vibrios: complexity for diversification. Int J Med Microbiol 296:61-71

NOAA (National Oceanic and Atmospheric Administration) (2007a) Station 46050, Stonewall Banks, 20NM West of Newport, OR. National Data Buoy Center, Stennis Space Center, MS. Available at: www.ndbc.noaa.gov/station page. .php? station $=46050$

NOAA (National Oceanic and Atmospheric Administration) (2007b) ERD upwelling indices. Pacific Fisheries Environmental Laboratory, Pacific Grove, CA. www.pfeg. noaa.gov/products/PFEL/modeled/indices/upwelling/up welling.htm

Sainz-Hernández JC, Maeda-Martínez AN (2005) Sources of Vibrio bacteria in mollusk hatcheries and control methods: a case study. Aquacult Res 36:1611-1618

Snedecor GW, Cochran WG (1989) Statistical methods, 8th edn. Iowa State University Press, Ames, IA

Thompson FL, Klose KE, the AVIB Group (2006) Vibrio2005: the first international conference on the biology of vibrios. J Bacteriol 188:4592-4596

> Thompson JD, Higgins DG, Gibson TJ (1994) CLUSTAL W: improving the sensitivity of progressive multiple sequence alignment through sequence weighting, position-specific gap penalties and weight matrix choice. Nucleic Acids Res 22:4673-4680

Tubiash HS, Chanley PE, Leifson E (1965) Bacillary necrosis, a disease of larval and juvenile bivalve mollusks, I. Etiology and epizootiology. J Bacteriol 90:1036-1044

Tubiash HS, Colwell RR, Sakazaki R (1970) Marine vibrios associated with bacillary necrosis, a disease of larval and juvenile bivalve mollusks. J Bacteriol 103: $2721-2723$

Tuttle JH, Holmes PE, Jannasch HW (1974) Growth rate stimulation of marine pseudomonads by thiosulfate. Arch Microbiol 99:1-4

Submitted: July 7, 2008; Accepted: September 10, 2008

Proofs received from author(s): November 16, 2008 